\title{
The effect of colostral immunoglobulin supplement on the passive immunity, growth and health of neonatal calves
}

\author{
Juha Nousiainen, Hannu Korhonen, Eeva-Liisa Syväoja, Sami Savolainen, Hannu Saloniemi \\ and HARRY JALONEN
}

\begin{abstract}
Nousiainen, J. ${ }^{1}$, Korhonen, H. ${ }^{2}$, Syväoja, E.-L. ${ }^{2}$, Savolainen, S. ${ }^{3}$, Saloniemi, H. ${ }^{3}$ \& JALONEN, $\mathrm{H}^{4}$ 1994. The effect of colostral immunoglobulin supplement on the passive immunity, growth and health of neonatal calves. Agricultural Science in Finland 3: 421-428. (' Farm Services, Valio Ltd, P.O. Box 390, FIN00101 Helsinki, Finland, ${ }^{2}$ Research and Development, Valio Ltd, P.O. Box 390, FIN-00101 Helsinki, Finland, ${ }^{3}$ College of Veterinary Medicine, Department of Animal Hygiene, P.O. Box 6, FIN-00581 Helsinki, Finland, and ${ }^{4}$ Valio Bioproducts Ltd, Biocity, Tykistökatu 6, FIN-20520 Turku, Finland.)
\end{abstract}

\begin{abstract}
Neonatal dairy calves were randomly allotted to three colostrum feeding regimens with increasing intakes of immunoglobulins ( $\mathrm{Ig}$ ) on the first day of life. The control group was fed one litre of pooled colostrum (Ig intake $19.5 \mathrm{~g}$ ). In two experimental groups, the pooled colostrum was supplemented with 0.5 or 1.5 litres of commercial Ig-concentrate, giving a total Ig intake of 52.7 and $119.0 \mathrm{~g}$, respectively. Serum $\mathrm{IgG}, \mathrm{IgM}$ and $\mathrm{IgA}$ levels increased linearly $(\mathrm{p}<0.001)$ on day 2 post partum with the increasing Ig intake. The calculated mean Ig-absorption rate was $61 \%$ and decreased linearly for $\operatorname{IgM}(p=0.051)$ and $\operatorname{IgG}(\mathrm{p}=0.078)$ with increasing $\operatorname{Ig}$ intake. At the highest Ig intake, serum IgG remained above $10 \mathrm{~g} / \mathrm{l}$ during 30 days post partum. In the experimental groups, serum IgM and IgA decreased sharply during the first week of life and were relatively constant thereafter. In the control group, however, there was an increase in serum IgM after one week post partum, perhaps due to the in situ production of Ig. With the increasing Ig intake there was a small and non-significant tendency for better live weight gain $(p=0.286)$ and a lower incidence of diarrhoea $(p=0.421)$ during the first four weeks of life. It is concluded that the Ig-product tested is well absorbed during 24 hours post partum and it can be used either as a supplement to maternal colostrum when its quality is poor, or as a substitute when colostrum is not available.
\end{abstract}

Key words: Ig supplement, immunoglobulin absorption, performance, diarrhoea

\section{Introduction}

Colostral immunoglobulins (Ig) provide primary protection against infections in newborn calves, since the bovine placenta does not allow transfer of macromolecules in significant amounts (LARSON et al. 1980). There is, however, a marked variation in the Ig level of the first colostrum, possibly owing to the length of the dry period, number of lactations, feeding and other management factors of cows (FLEENOR and SCOTT 1981, KRUSE 1970a). Hence, quite many of the neonatal calves may be agammaglobulinaemic (e.g. BRIGNOLE and SCOTT 1980).

It has been suggested that newborn calves should have a total minimum intake of $80-100$ grams of Ig (equals 2-3 litres of good quality colostrum) during the first 24 hours post partum 
(KRUSE 1970b, ScOTt et al. 1979c). After this period, the gut epithelium closes, and Ig ingested by the calf may have only local importance against pathogens. HANCOCK (1985) reported an increased risk of mortality in calves with serum Ig levels below $2.5 \mathrm{~g} / \mathrm{l}$, but the occurence of diarrhoea may already increase at levels below $10 \mathrm{~g} / \mathrm{l}$. In a recent Swedish field study (VIRING et al. 1993), the mean serum Ig level in 7-day-old calves was 5.9 $\mathrm{g} / \mathrm{l}$ and slightly less $(5.3 \mathrm{~g} / \mathrm{l})$ in diarrhoeic calves. The peak Ig level was detected in samples taken during the day 2 post partum, averaging $8.5 \mathrm{~g} / \mathrm{l}$.

Since it is clear that the colostral Ig-concentration and the amount and time of its ingestion affect the level of circulating antibodies in the serum of calves and consequently their passive protection against diseases (SCOTT et al. 1979a-c), many artificial rearing methods have been studied. For example, frozen bulk colostrum (BESSER et al. 1991), pooled colostrum powder (ZAREMBA et al. 1993) and purified Ig powder made from cheese whey (FIEMS et al. 1989) or bovine blood serum (ToDD et al. 1993) have been used as a partial or total supplement to dams' colostrum. However, little has been published about the absorption of different Ig classes from the different types of colostral supplement and their effect on the performance of neonatal calves has varied rather widely.

This study was designed to evaluate the effect of a commercial Ig preparation (Ig-C) given to supplement low-quality colostrum on the absorption of immunoglobulins, serum Ig level, growth and the occurrence of diarrhoea in neonatal calves.

\section{Material and methods}

\section{Diets and animals}

Twenty-one calves were divided at random into three groups, seven calves in each, and given one of the three feeding regimens (Table 1). Instead of dams' colostrum, the calves in the first group (control) were fed whole milk (WM) and pooled colostrum (PC). The other two groups were fed $\mathrm{WM}$ and $\mathrm{PC}$ and a commercial Ig concentrate (Ig-C) to give increasing controlled amounts of Ig from the first and second feeding in a constant volume (treat 1 and treat 2 ). In all groups the calves were first fed immediately post partum and the second time 8-12 hours later. In the control group, the Ig intake (about $20 \mathrm{~g}$ ) represented a level at which calves ingest low-quality colostrum, in the treat 1 group (about $50 \mathrm{~g}$ ) a level which may be minimally acceptable, and in the treat2 group ( $>100 \mathrm{~g})$ a level which may be regarded as safe.

WM was normal pooled milk from the experimental dairy herd. PC was collected from dairy farms in central and northeastern parts of Finland and was based on 1-5 milkings post partum. Colostrum was frozen on the farms, transported to a dairy factory, thawed, pooled and defatted by dairy separator. For usage in the feeding trial, PC was packed in 0.5-litre portions and frozen. Ig-C was commercially concentrated from PC by Valio Bioproducts Ltd., Turku, Finland. Casein was removed from PC by acid precipitation and the resulting whey was ultrafiltrated. The ultrafiltration retentate $(\mathrm{Ig}-\mathrm{C})$ was packed in 0.2 -litre portions, sterilized (gamma-radiation, minimum 25 $\mathrm{kGy}$ ) and frozen.

On days 4-56 of life all the calves were fed similarly with WM ( $10 \%$ of live weight), hay (ad lib) and commercial concentrate ( $\mathrm{ad}$ lib). The live weights of the calves were recorded immediately after birth and weekly thereafter until the age of 8 weeks. The faecal consistency was assessed daily during 28 days post partum on the following scale: hard (0), normal (1), soft (2) and diarrhoea (3).

\section{Sampling and analyses}

Three separate samples of PC and Ig-C were taken from the respective lots used in the feeding trial. Blood samples were drawn from vena jugularis with dry vacuum tubes at 2, 7, 14 and 30 days of age. The samples were allowed to stand at room temperature for $30 \mathrm{~min}$ and serum was then separated by centrifugation $(10 \mathrm{~min}, 2000 \mathrm{r}$ / 
Table 1. Feeding regimen during first four days of life.

\begin{tabular}{|c|c|c|c|c|}
\hline Treatment & $\begin{array}{c}\text { First } \\
\text { feding }\end{array}$ & $\begin{array}{l}\text { Second } \\
\text { feeding }\end{array}$ & Days 2-4 & Ig intake") \\
\hline Control & $\begin{array}{l}1.001 \mathrm{WM} \\
0.501 \mathrm{PC}\end{array}$ & $\begin{array}{l}1.001 \mathrm{WM} \\
0.501 \mathrm{PC}\end{array}$ & $31 \mathrm{WM}+\mathrm{PC}$-mixture ${ }^{*}$ & 19.5 \\
\hline Treat 1 & $\begin{array}{l}0.501 \mathrm{WM} \\
0.501 \mathrm{PC} \\
0.501 \mathrm{Ig}-\mathrm{C}\end{array}$ & $\begin{array}{l}1.001 \mathrm{WM} \\
0.501 \mathrm{PC}\end{array}$ & $31 \mathrm{WM}+\mathrm{PC}$-mixture*) & 52.7 \\
\hline Treat2 & $\begin{array}{l}0.251 \mathrm{WM} \\
0.501 \mathrm{PC} \\
0.751 \mathrm{Ig}-\mathrm{C}\end{array}$ & $\begin{array}{l}0.251 \mathrm{WM} \\
0.501 \mathrm{PC} \\
0.751 \mathrm{Ig}-\mathrm{C}\end{array}$ & $31 \mathrm{WM}+\mathrm{PC}$-mixture ${ }^{*}$ & 119.0 \\
\hline
\end{tabular}

$\mathrm{PC}=$ pooled colostrum; $\mathrm{WM}=$ whole milk; $\mathrm{Ig}-\mathrm{C}=$ colostral $\mathrm{Ig}$ concentrate.

*) Gradually decreasing proportion of PC (similar in all groups).

\#) Total intake from first and second feeding.

min, WIFUG model $\mathrm{X}-1$, Sweden) and stored at $-20^{\circ} \mathrm{C}$ for analysis for $\mathrm{IgG}, \mathrm{IgM}$ and $\mathrm{IgA}$. The concentrations of different Ig classes in PC, Ig-C and serum were analysed with radial immunodiffusion assay using commercial kits (Serotec, UK). The estimated coefficients of absorption of the Ig classes were calculated as the ratio between the serum pool on day 2 to total intake, assuming the serum volume to be $7 \%$ of the birth weight (see SCOTT and MENEFEE 1978).

\section{Statistical methods}

Serum Ig data on day 2, Ig absorption, live weights and growth were analysed with the regression analysis (Ig levels not equally spaced) with the following model $\mathrm{Y}_{\mathrm{ijk}}=\mu+\alpha \mathrm{T}(1)_{\mathrm{i}}+\beta \mathrm{T}(\mathrm{q})_{\mathrm{j}}+\varepsilon_{\mathrm{ijk}}$ (1), where $T(1)$ and $T(q)$ represent the linear and quadratic effects of increasing Ig intake, respectively, and $\varepsilon_{\mathrm{ijk}}$ deviations from the regression. In addition, the mean serum Ig levels and the treatment*age interaction was analysed with the split plot model $\mathrm{Y}_{\mathrm{ijklm}}=\mu+\alpha \mathrm{T}(\mathrm{l})_{\mathrm{i}}+\beta \mathrm{T}(\mathrm{q})_{\mathrm{j}}+\varepsilon_{\mathrm{ijk}}+\mathrm{A}_{1}+$ $\mathrm{TA}_{\mathrm{ijl}}+\varepsilon_{\mathrm{ijklm}}(2)$, where $\mathrm{T}(1), \mathrm{T}(\mathrm{q})$ and $\varepsilon_{\mathrm{ijk}}$ are as in the model (1), A is the effect of the age of the calves and $\varepsilon_{\mathrm{ijklm}}$ is the sub-plot error. The calculations were made with the SURVO statistical program (MUSTONEN 1987). Faecal consistency observations were analysed with the $\chi^{2}$ test according to SNEDEGOR and Cochran (1967).

\section{Results}

The concentrations of $\mathrm{IgG}, \mathrm{IgM}$ and $\mathrm{IgA}$ in PC were $17.4,1.9$, and $0.2 \mathrm{~g} / \mathrm{l}$ and in $\mathrm{Ig}-\mathrm{C} 55.8,9.2$ and $1.3 \mathrm{~g} / \mathrm{l}$, respectively. The calculated total $\mathrm{Ig}$ intakes from the first two feedings were 19.5, 52.7 and $119.0 \mathrm{~g}$ for the control, treat 1 and treat 2 groups, respectively (Table 1).

The estimated absorption coefficiency of $\mathrm{IgM}$ and IgA decreased linearly with increasing intakes $(\mathrm{p}=0.051$ and $\mathrm{p}=0.078$, respectively, Table 2). A similar tendency was noted for IgG, but due to the high variation at low Ig intakes the trend was not significant $(\mathrm{p}=0.221)$.

Increasing the Ig intake of the calves with Ig-C resulted in a linear response $(\mathrm{p}<0.001)$ to serum $\mathrm{IgG}, \mathrm{IgM}$ and $\mathrm{IgA}$ concentrations just after the absorption period on day 2 (Table 2). Serum IgG was above $10 \mathrm{~g} / \mathrm{l}$ between days 2 and 30 with the highest Ig intake (Treat2, Figure 1). In the control and treat 1 groups the minimum serum IgG was noted on days 7 and 14 , respectively, increasing thereafter. The serum IgM and IgA concentrations declined sharply during the first week post partum at both levels of the Ig C-intake (Figures 2 and 3 ) being fairly constant from then onwards. In the control group, however, the concentration of $\mathrm{IgM}$ increased steadily after day 7 , giving evidence of in situ production of $\mathrm{IgM}$. For all Ig classes the 
Table 2. Effect of the Ig concentrate on serum Ig levels and estimated absorption in treated calves between ages $2-30$ days.

\begin{tabular}{|c|c|c|c|c|c|c|}
\hline \multirow[t]{2}{*}{ Item } & \multirow[t]{2}{*}{ Control } & \multirow[t]{2}{*}{ Treat 1} & \multirow[t]{2}{*}{ Treat2 } & \multirow{2}{*}{$\begin{array}{l}\text { SEM } \\
18 \mathrm{df}\end{array}$} & \multicolumn{2}{|c|}{ Significance } \\
\hline & & & & & $\mathrm{L}$ & Q \\
\hline \multicolumn{7}{|c|}{ Absorption, \% } \\
\hline IgG & 68.8 & 57.5 & 45.4 & 7.42 & 0.221 & 0.828 \\
\hline IgM & 73.2 & 52.1 & 42.4 & 5.66 & 0.051 & 0.389 \\
\hline IgA & 87.9 & 71.9 & 50.1 & 8.25 & 0.078 & 0.850 \\
\hline \multicolumn{7}{|c|}{$\mathrm{IgG}, \mathrm{g} / \mathrm{l}$} \\
\hline 2 days & 4.2 & 8.2 & 15.1 & 0.84 & $<0.001$ & 0.832 \\
\hline mean & 4.8 & 6.8 & 12.3 & 1.24 & $<0.001$ & 0.696 \\
\hline \multicolumn{7}{|c|}{$\mathrm{IgM}, \mathrm{mg} / \mathrm{l}$} \\
\hline 2 days & 483.4 & 1092.1 & 2182.9 & 102.95 & $<0.001$ & 0.853 \\
\hline mean & 502.1 & 586.8 & 959.6 & 79.40 & $<0.001$ & 0.439 \\
\hline \multicolumn{7}{|c|}{$\mathrm{IgA}, \mathrm{mg} / \mathrm{l}$} \\
\hline 2 days & 60.1 & 193.9 & 360.0 & 21.52 & $<0.001$ & 0.478 \\
\hline mean & 17.3 & 61.2 & 111.8 & 11.66 & $<0.001$ & 0.337 \\
\hline
\end{tabular}

Treatments on first day after calving: Control $=1.01$ pooled colostrum $(\mathrm{PC})$, Treat $1=1.01 \mathrm{PM}$ plus $0.51 \mathrm{Ig}$ concentrate $(\mathrm{Ig}-\mathrm{C})$, Treat $2=1.01 \mathrm{PC}$ plus $1.51 \mathrm{Ig}-\mathrm{C}$.

Total Ig intake from first and second feeding: Control $19.5 \mathrm{~g}$, Treat $152.7 \mathrm{~g}$ and Treat $2119 \mathrm{~g}$.

Significance: $\mathrm{L}=$ linear response to $\mathrm{Ig}$ intake; $\mathrm{Q}=$ quadratic response to $\mathrm{Ig}$ intake. Treatment*age interaction for mean $\operatorname{IgG}, \operatorname{IgM}$ and $\operatorname{IgA}$ was significant $(\mathrm{p}<0.001$, see also figures $1-3)$. SEM = standard error of mean.

treatment*age interaction was highly significant ( $<<0.001$, Table 2, Figures 1-3).

Live weights (LW) and the LW gain of the calves are presented in Table 3 . The responses of live weight and live weight gain to increasing amounts of Ig-C were non-significant ( $\mathrm{p}>0.05$ ). There was a tendency for better LW gain during the first 28 days of life in calves treated with Ig$\mathrm{C}$ but between 28 and 56 days the differences between the groups were small.

The distribution of faecal consistency observations is presented in Table 4 . With increasing Ig intake there was a steady but non-significant $(p=0.421)$ tendency for a lower incidence of diarrhoea during the first month of life.

\section{Discussion}

This study was designed to evaluate the efficacy of a commercial Ig preparation (Ig-C) as a sup-

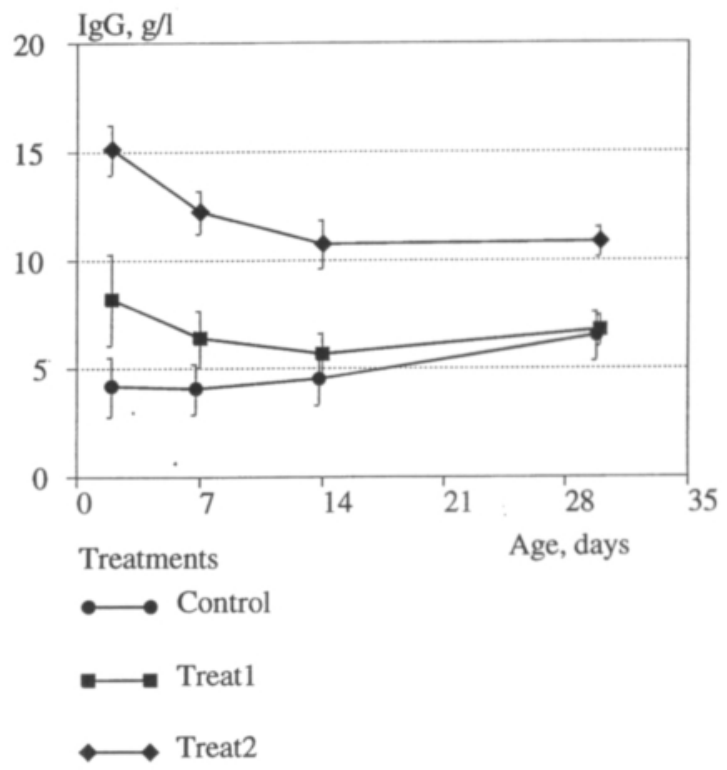

Fig. 1. Effect of Ig concentrate on IgG-level (mean \pm S.E.) in serum of neonatal calves. 


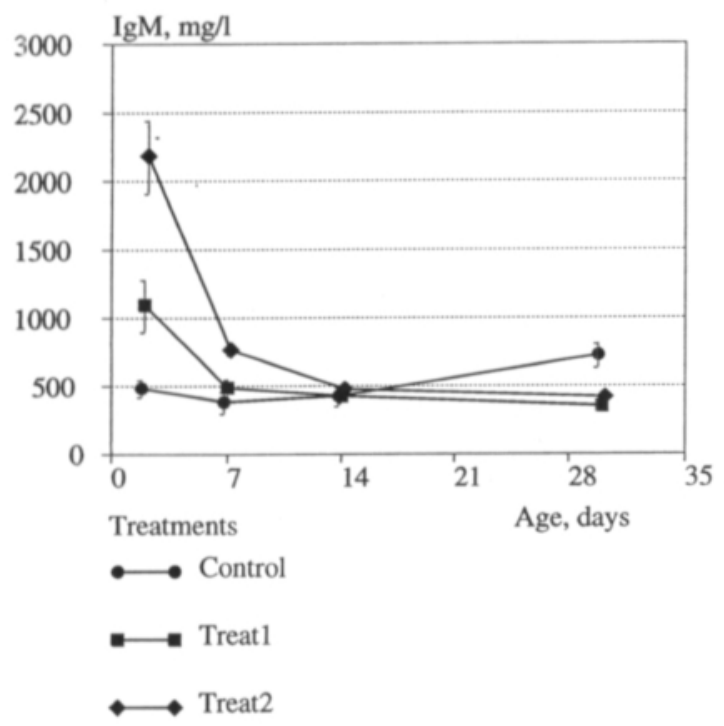

Fig. 2. Effect of Ig-concentrate on IgM-level (mean \pm S.E.) in serum of neonatal calves.

plement to low quality colostrum. According to the results, the dose response of the peak serum $\mathrm{IgG}, \mathrm{IgM}$ and $\mathrm{IgA}$ on day 2 to $\mathrm{Ig}-\mathrm{C}$ seems to be linear (Table 2) when mixed with pooled colostrum having a relatively low Ig content. In agreement with this study PETRIE (1984) found that the serum Ig level in calves increased linearly with increasing Ig concentration. SCOTT and FELLAH (1983), who fed calves different levels of Ig by

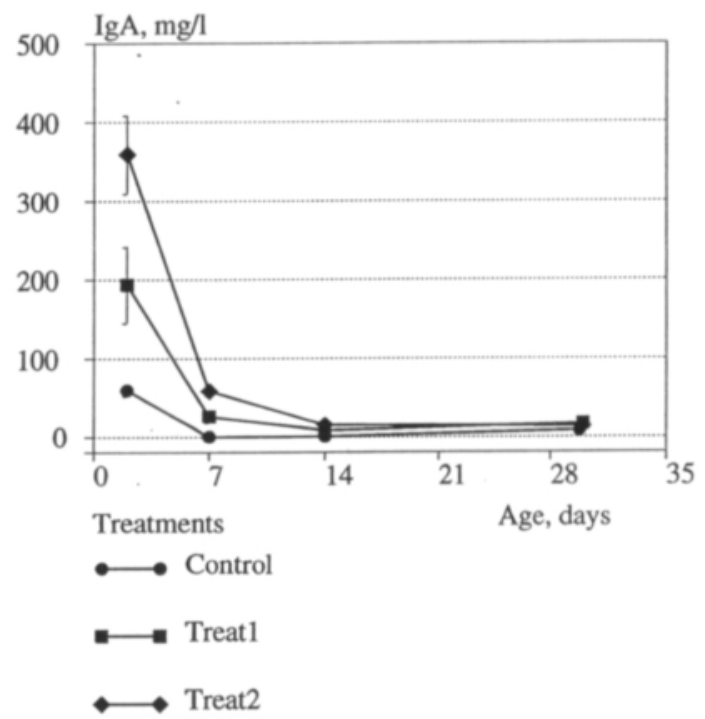

Fig. 3. Effect of Ig-concentrate on IgA-level (mean \pm S.E.) in serum of neonatal calves.

artificially varying the Ig concentration of colostrum, noted a linear increase in serum IgG and $\operatorname{Ig} \mathrm{A}$; in contrast to our findings, however, serum IgM concentrations had a quadratic response. In an earlier study, SCOTT and MENEFEE (1978) found that the coefficient of absorption for IgM was decreased, and was constant for $\mathrm{IgG}$ and $\mathrm{IgA}$ when amount ingested increased from 50 to $400 \mathrm{~g}$. BESSER et al. (1991) calculated a quadratic response

Table 3. Effect of the Ig concentrate on live weight and live weight gain in treated calves between ages 1 and 56 days.

\begin{tabular}{|c|c|c|c|c|c|c|}
\hline \multirow[t]{2}{*}{ Item } & \multirow[t]{2}{*}{ Control } & \multirow[t]{2}{*}{ Treat 1} & \multirow[t]{2}{*}{ Treat2 } & \multirow{2}{*}{$\begin{array}{l}\text { SEM } \\
18 \mathrm{df}\end{array}$} & \multicolumn{2}{|c|}{ Significance } \\
\hline & & & & & $\mathrm{L}$ & Q \\
\hline \multicolumn{7}{|c|}{ Live weight, kg } \\
\hline 1 day & 40.3 & 42.8 & 43.3 & 0.97 & 0.262 & 0.503 \\
\hline 28 days & 49.0 & 52.4 & 54.0 & 1.22 & 0.133 & 0.527 \\
\hline 56 days & 71.3 & 72.9 & 76.0 & 1.76 & 0.286 & 0.985 \\
\hline \multicolumn{7}{|c|}{ Weight gain, g/d } \\
\hline $0-28$ days & 309 & 343 & 381 & 18.6 & 0.286 & 0.809 \\
\hline $28-56$ days & 796 & 766 & 785 & 31.9 & 0.931 & 0.695 \\
\hline $0-56$ days & 553 & 550 & 583 & 22.4 & 0.546 & 0.796 \\
\hline
\end{tabular}

Significance: $\mathrm{L}=$ linear response to $\mathrm{Ig}$ intake; $\mathrm{Q}=$ quadratic response to $\mathrm{Ig}$ intake. 
Table 4. Effect of the Ig concentrate on occurrence of diarrhoea and soft faeces in treated calves between ages of 1 and 28 days.

\begin{tabular}{|c|c|c|c|c|c|c|}
\hline \multirow[t]{2}{*}{ Item } & Control & \multicolumn{2}{|c|}{ Treat1 } & \multicolumn{2}{|c|}{ Treat2 } & \multirow[t]{2}{*}{ Signficance } \\
\hline & f $\quad \%$ & f & $\%$ & f & $\%$ & \\
\hline
\end{tabular}

\begin{tabular}{|c|c|c|c|c|c|c|c|}
\hline $\begin{array}{l}\text { Distribution } \\
\text { of observations } \\
\text { - normal }\end{array}$ & 22.3 & $(80)$ & 24.6 & (88) & 25.7 & (92) & \\
\hline- soft & 3.3 & (12) & 3.0 & (11) & 1.7 & (6) & \\
\hline - diarrhoea & 2.3 & (8) & 0.4 & (1) & 0.6 & (2) & \\
\hline - soft + diarrhoea & 5.6 & $(20)$ & 3.4 & (12) & 2.3 & (8) & 0.421 \\
\hline
\end{tabular}

for serum IgG1 when the amount ingested increased from 20 to $300 \mathrm{~g}$ (constant volume of 2.84 1). The reason for the variable mode of absorption in single experiments might be the volume range of colostrum fed to calves and the method of varying the Ig intake. Here, the maximum total Ig intake was about $120 \mathrm{~g}$ during $24 \mathrm{~h}$ post partum, which is far lower than in the trials mentioned above (ScOTT and MenEFEE 1978, BESSER et al. 1991). In addition to the amount fed, the mode of absorption of Ig depends on the volume fed and the time of feeding (ScOTT and FELLAH 1983). Nevertheless, it may be reasonable to suggest that the mode of the peak serum Ig response is curvlinear at least with very high intakes, since the passive transfer system (pinocytosis) from the gut to the bloodstream may be saturated.

Our results suggest a linearly decreasing absorption efficiency of $\operatorname{IgM}$ and $\operatorname{IgA}$ with increasing intake. The decrease was 0.29 and 0.37 percentage units per $1 \mathrm{~g}$ increase of $\mathrm{Ig}$ intake for $\mathrm{IgM}$ and $\mathrm{IgA}$, respectively. The mean coefficients agree well with those presented by SCOTT and MenefeE (1978), although they noted selective absorption for $\operatorname{IgM}$ only with an increasing concentration in the colostrum. It is unclear wether Ig's were absorbed better from PC than from Ig-C, which was in fact processed from PC. First, increasing the Ig intake obviously lowers the absorption efficiency, and second, the present figures for absorption efficiency may be biased at low intakes, due to either analytical errors or the possibility of placental transfer of Ig. The rough regression estimates of pre-colostral serum values for IgG, IgM and IgA were $2.2,0.2$ and $0.02 \mathrm{~g} / \mathrm{l}$, respectively. In agreement with these figures, ZAREMBA et al. (1993) measured the serum IgG level between 1.2 and $1.4 \mathrm{~g} / \mathrm{l}$ after birth before ingestion of colostrum. On the other hand, the pre-colostral value may reflect a genuine immunogloblin synthesis by the foetal calf during pregnancy owing to antigenic stimulation as speculated by JENSEN (1978). These points need further investigation, since placental transfer or the in situ production before parturition is uncertain (see e.g. LARSON et al. 1980).

In general, the serum Ig level in calves decreases after birth, being lowest 3-4 weeks post partum (LOGAN 1974, JENSEN 1978). In the present trial, especially $\mathrm{IgM}$ and $\mathrm{IgA}$, but not IgG, were rapidly eliminated from the blood. The mean biological half life of $\operatorname{IgM}$ and $\operatorname{IgA}$ were 4.4 and 3.2 days, respectively, when calculated with regression between days 2 and 7. This is consistent with the results of JENSEN (1978). Owing to the significant treatment*age interaction in the serum Ig levels, we agree with LoGAN (1974) that in hypogammaglobunaemic calves in situ Ig syn- 
thesis may begin as early as one week post partum. This is evident for IgM (Figure 2), but the serum IgG-level also tended to increase between days 7 and 30 in the calves with the lowest Ig intake (Figure 1). However, the earlier in situ Ig synthesis does not compensate for adequate colostrum intake in practice.

A number of authors have reported a close relationship between the $\mathrm{Ig}$ level in serum and the performance of calves (see HANCOCK 1985 and STAAK 1992). The data reported here suggest a slightly improving weight gain and less diarrhoea during the first month with increasing Ig intake $(r=0.35)$. None of the calves died or suffered severe health problems, although the serum Ig remained below the expected boundary level $(5-10 \mathrm{~g} / \mathrm{l})$ in the control and treat 1 groups. This may reflect good management methods and low infection pressure on the experimental farm, since high passive immunity per se does not necessarily improve performance. Immunoglobulins from a pooled colostrum source, as in this study (Ig-C), may not be as effective against antigens on a certain farm as those from the dam. On the other hand, pooled colostrum may be beneficial for transported calves, because it evidently contains antibodies against a variety of microbial antigens. To obtain a better understanding of this question, the specific antibody titres for Ig-C should be studied.

In the trials discussed by HaLlidaY (1980), the relationship between growth and the Ig level in blood was closer in suckling lambs than in dairy calves. The weight gain of lambs was closely related to the ability of the dam to produce milk. In other words, not only serum Ig level, but also energy and protein intake may partly explain the weak relationship between passive immunity and growth in some trials. In many colostrum supplementation trials (e.g. ZAREMBA et al. 1993, FIEMS et al. 1989, ToDD et al. 1993), the response of growth and health status of calves to Ig supplements has been weak. Inadequate dosages, time of feeding or origin of the supplement may explain some of these results.

In conclusion, the concentrated Ig product tested here $(\mathrm{Ig}-\mathrm{C})$ caused a linear increase in the serum Ig level of dairy calves. About $0.5-1.0$ litres of the product is needed to reach a safe $\mathrm{Ig}$ level $(10 \mathrm{~g} / \mathrm{l})$ in the serum. Ig-C can be used either as a supplement to poor-quality maternal colostrum, or as a substitute when no colostrum is available.

Acknowledgements. We wish to thank the staff of the Suitia Research Farm, University of Helsinki, for providing facilities for the trial and for taking care of the calves.

\section{References}

Besser, T.E., Gay, C.C. \& Prichett, L. 1991. Comparison of three methods of feeding colostrum to dairy calves. Journal of American Veterinary Medical Association 198: 419-422.

BrignOle, T.J. \& ScOTT, G.H. 1980. Effect of suckling followed by bottle feeding colostrum on immunoglobulin absorption and calf survival. Journal of Dairy Science $63: 451-456$.

Fiems, L.O., Vanopdenbosch, E., Bouncque, Ch.V., VanCOILliE, Y. \& COTTYN, B.G. 1989. Effect of purified immunoglobulins or pooled colostrum on performance of rearing calves. Animal Feed Science and Technology 26 : 347-356.

FleENOR, W.A. \& SCOTT, G.H. 1981. Single radial immunodiffusion analysis for colostral immunoglobulin concentration. Journal of Dairy Science 64: 740-747.

HALLIDAY, R. 1980. Interrelationships between immunity and growth. In: Lawrence, T.L.J. (ed.). Growth in Animals. Butterworths, London, p.175-227.
HANCOCK, D.D. 1985. Assessing efficiency of passive immune transfer in dairy herds. Journal of Dairy Science 68: $163-183$.

JENSEN, P.T. 1978. Quantitative studies on immunoglobulins, albumin and total protein in serum from young normal calves. Nordisk Veterinärmedicin 30: 145-154.

KRUSE, V. 1970a. Yield of colostrum and immunoglobulin in cattle at the first milking after parturition. Animal Production 12: 619-626.

- 1970b. A note of the estimation by simulation technique of the optimal colostrum dose and feeding time at first feeding after the calf's birth. Animal Production 12: 661-664.

Larson, B.L., Heary, H.L. \& Devery, J.E. 1980. Immunoglobulin production and transport by the mammary gland. Journal of Dairy Science 63: 665-671.

LoGAN, E.F. 1974. Quantitative studies on serum immunoglobulin levels in suckled calves from birth to five weeks. Veterinary Record 94: 367-370. 
Mustonen, S. 1987. Survo 84 User's guide. 1st. ed. University of Helsinki, Department of statistics. 335 p.

PETRIE, L. 1984. Maximising the absorption of colostral immunoglobulins in the newborn dairy calf. Veterinary Record 114: 157-163.

ScotT, G.H. \& Fellah, A. 1983. Colostral Immunoglobulin absorption linearly related to concentration for calves. Journal of Dairy Science 66: 1329-1328.

-, Marx, D.B., Menefee, B.E. \& Nightingale, G.T. 1979a. Colostral immunoglobulin transfer in calves I. Period of absorption. Journal of Dairy Science 62: 1632-1638.

-, Marx, D.B., Menefee, B.E. \& Nightingale, G.T. 1979b. Colostral immunoglobulin transfer in calves II. Rate of absorption. Journal of Dairy Science 62: 17661773.

-, Marx, D.B., Menefee, B.E. \& Nightingale, G.T. 1979c. Colostral immunoglobulin transfer in calves III. Amount of absorption. Journal of Dairy Science 62: 1902-1907.

- \& MenEFEE, B.E. 1978. Selective absorption of immunoglobulin IgM in the newborn calf. Journal of Dairy
Science 61: 461-466.

SNEDEGOR, G.W. \& COCHRAN, W.C. 1967. Statistical methods. 6th ed. Iowa State University. 593 p.

STAAK, C. 1992. Bovine colostrum and protection of the neonatal animal. Berliner und Münchener Tierärztliche Wochenschrift 105: 219-224.

Todd, A.G., Whyte, P.B.D. \& CARrol, P.D. 1993. A comparison of serum immunoglobulin concentrations in neo-natal calves fed substitute colostrum. Australian Veterinary Journal 70: 154-155.

Viring, S., Olsson, S.-O., Alenius, S., EmmanuelsSon, U., Jacobsson, S.-O., Larsson, B., Linde, N. \& UGGLA, A. 1993. Studies of enteric pathogens and gamma-globulin levels of neonatal calves in Sweden. Acta Veterinary Scandinavica 34: 271-279.

Zaremba, W., Gutherbock, W.M. \& Holmberg, C.A. 1993. Efficacy of a dried colostrum powder in the prevention of disease in neonatal calves. Journal of Dairy Science 76: 831-836.

Manuscript received April 1994

\title{
SELOSTUS
}

\section{Ternimaitoa täydentävän immunoglobuliini-tiivisteen vaikutus vastasyntyneiden vasikoiden immuniteettiin, kasvuun ja terveyteen}

\author{
Juha Nousiainen, Hannu Korhonen, Eeva-Liisa Syväoja, Sami Savolainen, Hannu Saloniemi \\ ja HARRY JALONEN
}

Valio Oy, Alkutuotanto ja neuvonta, sekä Tutkimus ja tuotekehitys, Eläinlääketieteellinen Korkeakoulu ja Valio Biotuotteet Oy

Kokeessa selvitettiin kaupallisen ternimaidosta peräisin olevan Ig-tiivisteen vasta-aineiden imeytymistä ja vaikutusta vastasyntyneiden vasikoiden kasvuun ja ripulisuuteen. 21 vasikkaa jaettiin kolmeen seitsemän vasikan ryhmään, jotka saivat kasvavan määrän ternimaidon vastaaineita kahdella ensimmäisellä juottokerralla. Kahdella ensimmäisellä juottokerralla kontrolliryhmä sai yhteisternimaitoa 11 (Ig-saanti 19,5 g). Koeryhmissä vasikat saivat 11 yhteisternimaidon lisäksi 0.5 tai 1.51 kaupallista Ig-tiivistettä, jolloin vastaavasti Ig-saanti oli 52,7 ja $119,0 \mathrm{~g}$. Maitomäärä tasattiin kaikille ryhmille samaksi täysmaidolla.

Seerumin IgG-, IgM- ja IgA-pitoisuudet nousivat suoraviivaisesti Ig-saannin lisääntyessä. Keskimääräinen laskennallinen vasta-aineiden imeytymistehokkuus oli $61 \%$ ja se aleni lineaarisesti $\operatorname{IgM}: n$ ja $\operatorname{IgA}: n$ osalta. Eniten
Ig-tiivistettä saaneessa ryhmässä seerumin $\operatorname{IgG}$ pysyi yli $10 \mathrm{~g} / \mathrm{l}$ koko kokeen ajan, eli 30 päivää syntymästä. Molemmissa koeryhmissä seerumin IgM- ja IgA-tasot laskivat jyrkästi ensimmäisen elinviikon aikana, pysytellen sen jälkeen samalla tasolla aina 30 päivän ikään asti. Kontrolliryhmässä seerumin IgM-pitoisuus alkoi kuitenkin nousta ensimmäisen elinviikon jälkeen, johtuen mahdollisesti vasikan oman Ig-tuotannon alkamisesta. Ig-saannin noustessa vasikoiden kasvu parani ja ripulisuus väheni neljän ensimmäisen elinviikon, mutta erot eivät olleet tilastollisesti merkitseviä.

Tulokset osoittivat, että kokeessa tutkitun Ig-tiivisteen vasta-aineet imeytyvät hyvin 24 tunnin kuluessa syntymästä. Tuotetta voidaan käyttää vasikoille ensi sijaisesti emän ternimaidon lisäkkeenä, kun sen laatu on huono, tai korvikkeena kun sitä ei ole saatavilla. 